Studia Slavica Savariensia 2016. 1-2. 30-37

DOI: $10.17668 /$ SSS.2016.1-2.30

\author{
Silvestar Balić \\ (Pečuh, Mađarska)
}

\title{
NAKLADNIČKA DJELATNOST HRVATA U MAĐARSKOJ - PRISTUP KORPUSU, IZAZOVI, INTERPRETACIJSKE MOGUĆNOSTI
}

\begin{abstract}
We can talk about Croatians in Hungary as a special minority communityunder this name from the end of the First World War when they were separated from their mother country with state borders, too. After almost a century the publishing activity of this community - like many other intellectual and material products - has not been recorded, researched, interpreted, that is bibliologically processed. It has been tried to catch up with this lack within a project. As a first step of this project it is important to create an initial list of all Croatian editions in Hungary from 1920 onwards. Already during the creation of this database, the initial difficulties of Croatian publishing in Hungary are obvious, and by examining the resulting corpus some interpretive possibilities appear in the processing of the mentioned materials.
\end{abstract}

Keywords: Croatians in Hungary, publishing, book history

O Hrvatima u Mađarskoj, kao posebnoj manjinskoj zajednici pod ovim nazivom možemo govoriti od kraja Prvog svjetskog rata, od kada su od vlastitoga matičnog korpusa odvojeni i državnim granicama. Ni nakon blizu jednoga stoljeća nakladništvo ove zajednice - kao ni mnogi drugi intelektualni i materijalni proizvodi - nije detaljno evidentirana, istražena, interpretirana, dakle, bibliološki obrađena. Ovaj se nedostatak pokušava nadoknaditi u sklopu projekta čiji je prvi korak stvaranje inicijalnog popisa svih hrvatskih izdanja u Mađarskoj od kraja Prvog svjetskog rata naovamo. Već u prvim koracima stvaranja ove baze su bili očiti polazni problemi hrvatskoga nakladništva u Mađarskoj, navirala pitanja oko točnog definiranja građe, a uvidom u dobiveni korpus ubrzo su se pojavile neke interpretacijske mogućnosti, nametnula nova područja, koja iziskuju širi pristup. U ovom radu nastojat ćemo detaljno odrediti pojam hrvatskoga nakladništva u Mađarskoj, opisati proces prikupljanja podataka i ponuditi interpretacijske mogućnosti koje nam mogu dati odgovore na pitanja: što je bila, što je trenutno i što će biti nakladništvo Hrvata iliti hrvatska pisana riječ u Mađarskoj nakon tematiziranoga razdoblja. 


\section{Pristup hrvatskom nakladništvu u Mađarskoj}

Sve do Drugog svjetskog rata pristup nemađarskim manjinskim izdanjima unutar Mađarske je neznatan. Nakon uvođenja komunističkog sustava Partija je pokazala poseban pristup narodnosnom pitanju, otvorene su nove mogućnosti za veća manjinska istraživanja, ali do takvih pothvata još dugo godina nije došlo. Do godine preokreta u slučaju narodnosnog istraživanja je došlo nakon odluke CK Komunističke stranke Mađarske 1968. godine, od kada država odvaja znatna proračunska sredstva za razne djelatnosti koje se odnose na manjinske zajednice (CHOLNOKY, FUTALA, KERTÉSZ 1994: 19). Rezultat ovih postupaka je utemeljenje Državne knjižnice Gorki (Állami Gorkij Könyvtár - Državna knjižnica Gorki, kasnije Országos Idegennyelvü Könyvtár és Zenei Gyüjtemény - Državna knjižnica za strane jezike i zbirka audio materijala), koja je postala bazičnom knjižnicom narodnosti u Mađarskoj i, pored dokumentacijske djelatnosti, bila je zadužena za sabiranje i bibliografsku obradu narodnosne literature. Plod ovih djelatnosti je obrađena građa manjinskih tiskovina i tekstova o manjinskim zajednicama u Mađarskoj $\mathrm{u}$ razdoblju 1945.-1975. godine, što je OIK u više navrata predstavio javnosti u obliku posebnih izdanja pod naslovom „Narodnosti u Mađarskoj“. Godine 1991. Državna knjižnica za strane jezike i zbirka audio materijala (OIK) objavila je dvotomnu retrospektivnu bibliografiju Hrvata, Srba i Slovenaca u Mađarskoj u spomenutoj seriji, kao peti svezak nakon bibliografije Nijemaca, Rumunja i Slovaka u Mađarskoj ${ }^{1}$. Riječ je o selektivnoj bibliografiji koja obrađuje razdoblje između 1945.-1975. i uključuje „samo“ periodiku na mađarskom i hrvatskom (te srpskom i slovenskom) jeziku, dok knjige na hrvatskom jeziku nisu uvrštene u taj popis (ili samo djelomično).

Najveći bibliografski projekt Hrvata u Mađarskoj do sada potpisuje urednik István Käfer, a najveći dio građe sakupila je Bibliografska radna grupa Mađarske akademije znanosti pod vodstvom Gábora G. Keménya (KÄFER 1991: 13). Na ukupno 1279 stranica nalazi se 13491 bibliografska jedinica koje su razvrstane u šest većih tematskih skupina. Svaka veća tematska cjelina podijeljena je na bezbroj manjih, a na kraju, pomoću indeksa pojmova brzo i lako možemo naći sadržaj koji nas zanima.

OIK nastavlja ovu djelatnost izdavanjem godišnjaka pod naslovom „Narodnosti u Mađarskoj: Selektivna bibliografija narodnosne literature i domaće literature o narodnostima“ koja popisuje tekuću građu na jezicima manjinskih zajednica u Mađarskoj i tekstove o njima, te izlazi od 1986. do 1992. (obrađuje razdoblje 1985.-1991.)². Ova je serija OIK-a metodološki

\footnotetext{
1 Käfer, István (ur.). Horvátok, szerbek, szlovének Magyarországon: Bibliográfia: 1945-1975 I.-II. = Hrvati, Srbi, Sloveni u Madjarskoj: Bibliografija: 1945-1975 I.-II. Budapest: OIK, 1991.

2 Nádor B, Orsolya (ur.). Nemzetiségek Magyarországon. A nemzetiségi és a nemzetiségekre vonatkozó hazai válogatott irodalom bibliográfiája 1985-1991. Budapest: Állami Gorkij Könyvtár - Országos Idegennyelvű Könyvtár, 1986-1992.
} 
slična prethodnoj bibliografiji, podijeljena je tematski i prema pojedinim narodnostima.

Sastavljanje takvih popisa nastavljeno je i nakon demokratskih promjena, također pod okriljem istraživačkih grupa OIK-a. Od 1993. godine izlazi nova serija pod skoro istim naslovom (podnaslov: Selektivna bibliografija literature o domaćim nacionalnim i etničkim manjinama), koja obrađuje narodnosnu produkciju od 1992. godine. Nakon ove serije OIK obustavlja svoju djelatnost objavljivanja manjinskih bibliografija, a prema planovima, publikacija manjinskih bibliografija nastavlja se u digitalnom obliku.

Pristup hrvatskom nakladništvu u Mađarskoj sa strane bibliografske prakse u Hrvatskoj možemo predstaviti pomoću nekoliko primjera, poput Hrvatske retrospektivne bibliografije knjiga 1835.-1940. (HRB) ili zbirke Inozemna Croatica, koji osim produkcije unutar Hrvatske kane obraditi i nakladništvo iseljeništva, dakle i Hrvata u Mađarskoj, koje također pripada svekolikoj hrvatskoj kulturnoj baštini, stoga treba biti zastupljeno i u takvim popisima. To potvrđuju i riječi Urednika Hrvatske retrospektivne bibliografije knjiga, Slavka Harnija: „Uvrštavanje iseljeničkog tiska prikupljenog u ostvarenim vezama s iseljeništvom nije samo predstavljanje do sada manje poznatih hrvatskih autora i njihovog rada široj javnosti - prilog je to brisanju podjele na domovinsku i iseljenu Hrvatsku kao negativnom povijesnom nasljeđu. Time se iskazuje integralni kulturni i povijesni identitet hrvatskog naroda u okviru zajedničkog jedinstvenog korpusa kulturnog nasljeđa“" (HARNI 2016).

Međutim, potpunost ili cjelovitost građe koja je nastala „u ostvarenim vezama s iseljeništvom“ ovisi o samim naporima iseljene hrvatske zajednice oko stvaranja takvog popisa, a kako smo naveli, u slučaju Hrvata u Mađarskoj takva istraživanja nisu provedena. Zbog ovih okolnosti, na žalost, ni sama nacionalna građa ili bibliografija ne može biti cjelovita.

Približavanje matične domovine svojim zajednicama izvan granica Republike Hrvatske je i pokretanje posebnog odsjeka pod nazivom inozemna Croatica u sklopu NSK. Od 2007. godine ciljano se radi na prikupljanju građe koja je izdana izvan Hrvatske i na bilo koji način se može povezati s Hrvatima ili s Hrvatskom. Ovdje se ne nalaze isključivo izdanja manjinskoga karaktera, već i npr. prijevodi domaćih hrvatskih književnika na razne jezike svijeta ili znanstvena djela o nekom aspektu hrvatske povijesti, kulture, jezika itd. Građa se nabavlja kupnjom, donacijama ili zamjenom (LOVRENČIĆ 2009: 136). Danas se ona dijeli na tri cjeline:

- gore spomenuta građa iz svijeta, tj. prijevodi hrvatskih autora, tekstovi na hrvatskom jeziku ili pak knjige u čijem sastavljanju nekakvu ulogu igra osoba hrvatskoga porijekla;

- Iseljenička knjiga: zbirka hrvatskih knjiga Nacionalne i sveučilišne knjižnice koja se čuvala u zatvorenome spremištu, a objavljene su do 1990. godine izvan prostora Republike Hrvatske; 
- Tisak hrvatskih manjina: sva izdanja koja se vezuju uz tematiku hrvatskih nacionalnih manjina u Austriji, Češkoj, Mađarskoj, Slovačkoj, Rumunjskoj, Italiji, Srbiji, Crnoj Gori i na Kosovu (MACHALA 2016: 8).

\section{Vrijeme, prostor, jezik i čitatelji}

Korpus koji se namjerava obraditi u okviru našega projekta, zvan nakladništvo Hrvata u Mađarskoj potrebno je odrediti detaljnije, jasno definirati koja izdanja pripadaju našem popisu, koja ne, i zbog čega. Tematizirana građa određena je prema trima glavnim kriterijima: vremenski, prostorni (geografski) i jezik publikacije (publika kao podkriterij). Kao poseban kriterij nije navedena vrsta građe jer se pod pojmom nakladništva podrazumijevaju produkti nakladničke produkcije u tradicionalnom obliku: knjige, serijska izdanja, te manji oblici poput brošura, kataloga izložaba, turističkih vodiča i sl.

Određivanje početnog razdoblja je povezano s nastankom fenomena „Hrvati u Mađarskoj “3. O toj zajednici (Hrvatima u Mađarskoj) pod ovim nazivom možemo govoriti tek od odvajanja dijela hrvatske zajednice od svoga matičnog korpusa, tj. od nastanka novih država nakon Prvog svjetskog rata, kada je dio Hrvata ostao na području Mađarske (BLAŽETIN 1998:6). Budući da je proces nastanka novih granica trajao nekoliko godina (1918.-1925., od završetka ratnih operacija sve do povlačenja vojske Kraljevine SHS s područja južne Mađarske i utvrđivanja novih granica na terenu) početnom godinom određujemo kraj Prvog svjetskog rata, 1918. godinu, kada je bilo jasno da će se odnosi na području gdje u većem broju žive Hrvati (Srednja i Jugoistočna Europa) radikalno promijeniti, a završnom 2015. godinu.

Prostorne granice građe su pomalo jasnije, njihovo određivanje je možda jednostavnije, ali isto, samo na prvi pogled. Naime, konačne granice Mađarske nakon Prvog svjetskog rata ostale su skoro iste sve do danas, stoga, razmatrat će se publikacije koje su izdane unutar granica Mađarske prema stanju nakon određivanja konačnih granica ${ }^{4}$. Međutim, ne smije se zaboraviti razdoblje Drugog svjetskog rata i tzv. Bečke odluke, putem kojih je Mađarska vratila jedan dio područja koja su nakon Prvog svjetskog rata pripojena susjednim državama. Mada je analiza nakladničke prakse okupiranih područja vrlo zahvalan posao, produkcija ovih prostora ne ulazi u predmet ovoga rada.

\footnotetext{
${ }^{3}$ Pored pojma „mađarski Hrvati” koji je također u uporabi, prednost dajemo i koristimo oblik „Hrvati u Mađarskoj”.

${ }^{4}$ Današnje granice Mađarske nisu u potpunosti identične s onima koje su određene temeljem mirovnog ugovora, ali razlike su minorne i odnose se na pogranična, nenastanjena područja gdje se nije vršila nakladnička djelatnost.
} 
Možda od svih kriterija najvažniji je ključ jezika. Svako izdanje koje se nalazi na našem popisu djelomično ili potpuno je pisano hrvatskim jezikom ${ }^{5}$. Međutim, tijekom jednog stoljeća pismenosti Hrvata u Mađarskoj i ovdje možemo naići na siva područja, koja proizlaze iz statusa hrvatskoga jezika, koji ni dan danas u mnogim knjižnicama diljem svijeta ne uživa potpunu samostalnost, pa tako ni u Mađarskoj. Nameće se pitanje, trebamo li uzeti u obzir samo izdanja napisana na hrvatskom jeziku? Mišljenja smo da u ovom slučaju, i općenito kod svakog izdanja na našem popisu, trebamo razmotriti kome je tekst, publikacija namijenjena (kriterij publike). Ako je npr. udžbenik iz zemljopisa pisan srpskim jezikom, ćirilicom, ali je namijenjen i Hrvatima u Mađarskoj, i iz nje će učiti i Hrvati u Mađarskoj, onda ovo izdanje ulazi u naš popis.

Unutar kriterija jezika, odnosno po zastupljenosti hrvatskoga jezika unutar pojedinih izdanja, možemo razlikovati barem tri kvalitativne kategorije. U prvu skupinu spadaju knjige i periodike koje su pisane samo na hrvatskom jeziku. One su u slučaju naše analize najvrjednija izdanja.

Drugu skupinu predstavljaju dvojezična izdanja, često zbirke književnih djela ili u novije vrijeme projektna izdanja financirana iz fondova Europske Unije, a u treću skupinu možemo uvrstiti knjige ili serijska izdanja koja su izdana na mađarskom jeziku, ali sadrže tekstove i na hrvatskom jeziku. Česti primjeri takvih knjiga su zbornici znanstvenih skupova, u kojima nalazimo radove na raznim jezicima.

\section{Metode prikupljanja}

Prvi korak na putu sastavljanja ovog popisa je bilo formiranje metode prikupljanja jedinica. Proces prikupljanja podijeljen je na tri faze: 1 . Pregled digitalnih kataloga državnih i regionalnih knjižnica; 2. Rezultati dosadašnjih istraživanja; 3. „Terenska“ istraživanja (prikupljanje podataka u kontaktu s lokalnim ustanovama, samoupravama, pojedincima).

Zahvaljujući digitalizaciji knjižničnih kataloga veliku većinu ovih izdanja možemo naći u bazama podataka spomenutih institucija. Pored državnih knjižnica pregledani su i katalozi većih regionalnih biblioteka u onim mađarskim gradovima u kojima tradicionalno bilježimo hrvatsko stanovništvo, ili gdje u okolnim naseljima i dan danas postoji aktivna hrvatska zajednica. Obradom digitalnih kataloga navedenih knjižnica prema definiranim kriterijima dobili smo popis od preko 900 jedinica.

Druga faza prikupljanja podataka sadrži one radove, novinske članke ili bilo koju publikaciju koji tematiziraju objavljena izdanja. Kako smo već naveli, bilo koji pothvat sličnih razmjera, stvaranje popisa ili bibliografije koji obrađuju

\footnotetext{
${ }^{5} \mathrm{~S}$ time se isključuju publikacije koje govore o hrvatskoj zajednici u Mađarskoj na drugim jezicima, dakle isključuje se pogled izvana koji je također važan segment percepcije zajednice, ali tek nakon obrade, shvaćanja i razumijevanja procesa koji su se događali unutar same zajednice možemo prijeći na analizu pogleda izvana.
} 
jedno razdoblje hrvatskog nakladništva u Mađarskoj ne postoji, stoga u ovoj drugoj fazi mogli smo se oslanjati samo na manje publikacije koje se bave s jednom (najčešće zaboravljenom serijskom) publikacijom. Takvi su tekstovi objavljeni u hrvatskim tjednicima, kalendarima, časopisima, zbornicima tijekom zadnjih 70 godina (Naše/Narodne novine, Naš/Narodni kalendar, Hrvatski glasnik, Hrvatski kalendar, Pogledi, Riječ itd.) u obliku stručnih i preglednih radova, prikaza, osvrta itd. Time dolazimo do začaranog kruga, budući da prikupljanje podataka na taj način predstavlja ozbiljan problem zbog nedostatka potrebne bibliografije koja obrađuje sadržaj spomenutih serijskih izdanja. U ovoj fazi zabilježeno je oko stotinjak izdanja.

$\mathrm{S}$ trećom fazom dolazimo do najzahtjevnijeg dijela prikupljanja materijala. Evidentiranje i arhiviranje pojedinih izdanja knjižnice ne odrađuju oduvijek, zbog čega mnoga starija izdanja ne možemo naći u katalozima, a nije rijetko da se i danas objavi poneko izdanje bez da je registrirano u Državnoj knjižnici Széchenyi, bez ISBN ili ISSN brojeva. Čim dublje prodiremo u prošlost, tim je manja mogućnost da će objavljeno izdanje biti prisutno u knjižnicama, a ova definicija se naročito odnosi na izdanja nacionalnih manjina.

Zbog toga, od izrazite je važnosti uključivanje ustanova, institucija i pojedinaca koji svoju djelatnost obavljaju na lokalnoj ili regionalnoj razini, kod kojih se mogu pronaći podaci koji u većim knjižnicama nisu registrirani. Ovo je ujedno i najdugotrajniji pothvat jer je potrebno doći do svih hrvatskih naselja diljem Mađarske. Riječ je o području od Gradišća do Bačke, više stotina kilometara udaljenosti, gdje djeluje 112 lokalnih hrvatskih samouprava, a broj naselja u kojima je u prošlosti bivalo hrvatsko stanovništvo je još veće ${ }^{6}$.

Glede prikupljanja podataka dolazimo do zaključka da je riječ o procesu koji se ne može smatrati dovršenim, uvije će se naći poneko izgubljeno izdanje koje bi trebalo biti na našem popisu. Tako i ovaj popis je tek inicijalan i autor se nada da će se tijekom godina nadopunjavati s nepoznatim jedinicama koje se možda ne čuvaju u državnim i regionalnim ustanovama, ali čine važan dio hrvatske pisane kulture ne samo u Mađarskoj, već i širem svijeta.

\section{Autor, nakladnik, publika}

Nakon prve i djelomično odrađene druge i treće faze prikupljanja podataka dobili smo popis od preko tisuću jedinica ${ }^{7}$. U slučaju bibliografskih jedinica zapisani su sljedeći podaci: autor (ili urednik); naslov (podnaslov, ako ima i na mađarskom jeziku); mjesto izdanja; izdavač; godina izdanja; opaske (npr. ako se iz naslova ne može naslutiti da u izdanju ima i hrvatskog sadržaja).

\footnotetext{
${ }^{6}$ Ovdje bi najkorisnija bila mreža lokalnih hrvatskih samouprava, međutim rad dodatno otežava činjenica da često ni same lokalne zajednice ne vode evidenciju o izdanjima koja su bila u uporabi u naselju, ni pismeno, niti u obliku kolektivnog pamćenja, mada skoro u svakom većem naselju postoji dom kulture ili knjižnica.

7 Kako smo na to skrenuli pažnju, prikupljanje podataka se ne može smatrati završenim, stoga u vremenu čitanja ovoga teksta ovaj će broj vjerojatno biti veći.
} 
Pored pukih podataka, same bibliografske obrade, naš korpus se namjerava analizirati detaljnije, namjerava se dati jedno tumačenje hrvatske nakladničke prakse u Mađarskoj kako bi dobili uvid u sustav nakladništva preko njenih glavnih aktera: autora, nakladnika i publike ${ }^{8}$.

U ovom trojstvu posebnu pozornost posvećujemo zadnjoj, prema našem mišljenju najvažnijoj komponenti (koja je, naravno, u izravnoj povezanosti s prvom) te ćemo pokušati opisati koji su vanjski čimbenici utjecali na recipijente i nakladnike hrvatskih izdanja u Mađarskoj.

Tematizirano razdoblje koje obuhvaća blizu jedno stoljeće, podijelit će se na tri veća perioda: 1. Između dva svjetska rata (1918.-1945.); 2. Od kraja Drugog svjetskog rata do osamostaljenja Hrvatske (1946.-1991.); 3. Nakon demokratskih promjena (od 1991.).

Kako bi se stvorio povijesno-društveni kontekst i shvatio odnos između tri glavna aktera nakladništva, potrebno je dati povijesni pregled o Hrvatima u Mađarskoj gdje će se istaknuti specifični povijesni i društveni događaji i procesi koji su utjecali na Hrvate u Mađarskoj.

Posebna pozornost se posvećuje književnim i kulturnim časopisima koji su se kod Hrvata u Mađarskoj pojavili tek krajem 20. stoljeća; ispitat će se njihova uloga u evoluciji književnosti Hrvata u Mađarskoj.

Druga velika skupina koja zavređuje poseban pregled su hrvatski udžbenici u Mađarskoj koji se u velikom broju pojavljuju nakon Drugog svjetskog rata sve do danas. Budući da oni izrazito utječu na čitateljsku publiku, formiraju buduće čitatelje, u otkrivanju čitateljskih navika trebaju biti pod povećalom naše interpretacije. Godišnja izdanja poput kalendara godinama su bila jedino štivo na hrvatskom jeziku na ovim prostorima, stoga, njihova obrada može dati važne odgovore na postavljena pitanja ovoga rada.

\section{Ideologije i identiteti}

Uvidom u dobiven korpus oblikovala se slika o nakladničkoj praksi na koju su izrazito utjecali organi izvan same hrvatske zajednice i zbog toga neprekidno, sve do demokratskih promjena, nakladnički i uređivački koncepti su pod utjecajem raznih ideologija, političkih pravaca i Crkve, ovisno o danom razdoblju.

Cilj nam je opisati ulogu takvih pravaca u manjinskim tiskovinama, njihov utjecaj na čitateljsku publiku i predstaviti posljedice takvih uređivačkih koncepcija na nacionalni identitet Hrvata u Mađarskoj. Do sada se kroatistika u Mađarskoj nije bavila pitanjem nacionalnog identiteta u hrvatskim izdanjima u Mađarskoj, stoga je analiza ovog područja ključna za razumijevanje drugih problematičnih pojava koje se događaju unutar ove zajednice.

${ }^{8} \mathrm{O}$ nakladništvu manjinskih zajednica u Mađarskoj postoji vrlo skromna literatura, vidi: Lukáts János: Szerkezet és tartalom. Kísérlet a magyarországi nemzetiségek könyvkiadásának elemzésére 1990-1999. In: Könyv, könyvtár, könyvtáros, 2001/3, 2235 
Na kraju ovog uvoda potrebno je naglasiti da zbog mnogih nedostataka kroatistike u Mađarskoj, bez većih, opsežnih pregleda raznih disciplina (povijest, jezik, etnologija itd.) na državnoj te na lokalnoj razini, ni uvodni pregledi ovoga rada ne mogu biti potpuni i odgovoriti na sva postavljena pitanja o Hrvatima u Mađarskoj.

\section{Literatura}

BLAŽETIN 1998 = BLAŽETIN S. Književnost Hrvata u Mađarskoj od 1918. do danas. Matica hrvatska, Osijek, Hrvatski znanstveni zavod, Pečuh, 1998.

CHOLNOKY, FUTALA, KERTÉSZ 1994. = CHOLNOKY GY., FUTALA T., KERTÉSZ GY. Nemzetiségi bibliográfia és dokumentáció hazánkban a kezdetektől napjainkig 2. // Könyvtári figyelö, 40, № 1. 5-28.

HARNI $=$ HARNI S. Hrvatska retrospektivna bibliografija knjiga. Nacionalna i sveučilišna knjižnica, Zagreb http://bibliografija.nsk.hr/hrb/ Pristup ostvaren: 20.09.2016.

KÄFER 1991 = KÄFER I. (ur.). Horvátok, szerbek, szlovének Magyarországon: Bibliográfia: 1945-1975 I.-II. / Hrvati, Srbi, Sloveni u Madjarskoj: Bibliografija: 1945-1975 I.-II. Budapest: OIK, 1991.

LOVRENČIĆ 2009 = LOVRENČIĆ Ž. Inozemna Croatica u Nacionalnoj i sveučilišnoj knjižnici u Zagrebu // Vjesnik bibliotekara Hrvatske 52, № 1/4. 135-142.

MACHALA = MACHALA L. (ur.). Smjernice za izgradnju zbirke Croatica. Zagreb: Nacionalna i sveučilišna knjižnica, 2016. 